\title{
ODSTUPANJA OD NAČELA JEDINSTVA NASLJEĐIVANJA U UREDBI EU-a O NASLJEĐIVANJU
}

Sažetak: $\quad$ Nasljeđivanje bi trebalo biti uređeno predvidljivim pravom koje je s njime blisko povezano. Radi izbjegavanja fragmentacije nasljedivanja i pravne sigurnosti, to bi pravo trebalo uređivati cjelokupno nasljedivanje, odnosno, cijelu ostavinu, bez obzira na to je li ta imovina pokretna ili nepokretna i je li smještena u nekoj državi članici Europske unije ili u državi koja nije njezina članica, odnosno trećoj državi. Uredba (EU) br. 650/2012 o nasljeđivanju u većini slučajeva slijedi navedenu ideju načela jedinstva nasljeđivanja, međutim, od nje odstupa prije svega kada su u postupak nasljeđivanja uključene treće države. Naime, u slučajevima povezanim s trećim državama, uspostavljanje podudarnosti između nadležnosti i mjerodavnog prava pokazalo se nemogućim, budući da raspodjela nadležnosti među sudovima država članica sukladno toj Uredbi ne uzima u obzir mogućnost da u takvim slučajevima imaju potpunu nadležnost sudovi trećih država s kojim nasljeđivanje ostvaruje značajnu povezanost. U tim slučajevima stoga može doći do fragmentacije nasljeđivanja podjelom nadležnosti na sudove države članice $i$ sudove trećih država, a što sa sobom nosi opasnost paralelnih postupaka s moguće različitim ishodima. Cilj rada je analizirati u kojim sve slučajevima na temelju Uredbe o nasljeđivanju dolazi do fragmentacije nasljedivanja i jesu li takva odstupanja opravdana te predložiti moguća rješenja. Zaključno se stoga predlažu izmjene koje bi omogućile strankama da se sporazume da su sudovi trećih država odabranog prava i nadležni za rješavanje pitanja nasljeđivanja, pod uvjetom da su ti sudovi tada nadležni za odlučivanje o nasljedivanju u cjelini. Osim toga, uvođenje u Uredbu o nasljeđivanju posebnih pravila o priznavanju i izvršenju odluka o nasljeđivanju donesenih od sudova trećih država osiguralo bi veću razinu ujednačenosti u tretiranju trećih država u odnosu na države članice Europske unije i time osiguralo i veći stupanj uvažavanja jedinstvenog pristupa nasljeđivanju kao jednog od njegovih temeljnih načela.

Ključne riječi: $\quad$ načelo jedinstva nasljeđivanja, Uredba o nasljeđivanju, nadležnost, mjerodavno pravo, treće države

Dr. sc. Katarina Knol Radoja, docentica, Pravni fakultet Sveučilišta Josipa Jurja Strossmayera u Osijeku, Stjepana Radića 13 31000 Osijek. Adresa e-pošte kknol@pravos.hr. ORCID: https://orcid.org/0000-0003-0275-3076. 


\section{UVOD}

Prekogranični ostavinski postupci donedavno mogli su se voditi s potencijalno suprotnim ishodima s obzirom na to da su sudovi u različitim državama istodobno mogli primjenjivati različita nacionalna prava. Osim toga, zainteresiranim osobama bile su sužene mogućnosti odabira mjerodavnog prava i suda nadležnog u njihovu ostavinskom predmetu.

U cilju uspostave Europske unije kao područja u kojem je osigurana sloboda, sigurnost i slobodno kretanje osoba, donesen je niz mjera koje se odnose na pravosudnu suradnju u građanskim stvarima s prekograničnim učinkom. U skladu s člankom 81/2. točkom (c) Ugovora o funkcioniranju Europske unije, ${ }^{1}$ takve mjere mogu uključivati mjere za osiguranje usklađenosti pravila koja se primjenjuju kod sukoba zakona i nadležnosti država članica. Kao mjera koja bi trebala pridonijeti tome da se zapreke slobodnom kretanju osoba suočenih s teškoćama pri ostvarivanju nasljednih prava s prekograničnim elementima uklone, u Europskoj je uniji 4. srpnja 2012. godine usvojena Uredba (EU) br. 650/2012 Europskog parlamenta i Vijeća o nadležnosti, mjerodavnom pravu, priznavanju i izvršavanju odluka i prihvaćanju i izvršavanju javnih isprava u nasljednim stvarima i o uspostavi Europske potvrde o nasljeđivanju² (dalje: Uredba o nasljeđivanju, Uredba).

Uredba o nasljeđivanju primjenjuje se na nasljeđivanje osoba umrlih nakon 17. kolovoza 2015. godine. Kao što iz njezina punog naziva proizlazi, u vezi s nasljeđivanjem sveobuhvatno uređuje nadležnost, mjerodavno pravo, priznavanje i izvršavanje odluka i prihvaćanje i izvršavanje javnih isprava i uspostavu Europske potvrde o nasljeđivanju, a ovaj rad detaljnije će se baviti osiguranjem jedinstvenog pristupa nasljeđivanju analizirajući pravila o nadležnosti i to posebno u odnosu na države koje nisu članice Europske unije.

U Preambuli 23. Uredbe o nasljeđivanju naglašava se potreba osiguranja pravilnog djelovanja pravosuđa u Uniji i postojanje stvarne poveznice između nasljeđivanja i nadležne države članice, a u Preambuli 27. navodi se kako je Uredba zamišljena tako da se osigura da u većini situacija tijelo koje odlučuje o nasljeđivanju primjenjuje svoje pravo. Uredba je jasno dakle inspirirana težnjom za usklađivanjem, odnosno paralelizmom između nadležnosti i primjenjivog zakona kad su posrijedi sporovi o nasljeđivanju. ${ }^{3}$

Pravila o nadležnosti u Uredbi o nasljeđivanju uključuju nekoliko objektivnih povezujućih čimbenika: uobičajeno boravište, državljanstvo i mjesto imovine. Nedostatak uobičajenog boravišta ili će dovesti do supsidijarne nadležnosti države članice temeljene prvenstveno na mjestu imovine ili na forum necessitatis na temelju nedostatka drugog odgovarajućeg foruma. Uredba nema konkretnu definiciju koje se sve države smatraju trećim državama, dok su u smislu Preambule 82. i 83. Uredbe države članice sve države članice osim Danske, Ujedinjene Kraljevine i Irske. Stoga se u literaturi postavilo pitanje jesu li i te države treće države kao i svaka druga država izvan Europske unije ili čine treću kategoriju, odvojeno od država članica

1 Ugovor o funkcioniranju Europske unije (pročišćeni tekst), Službeni list C 326, 26. listopada 2012., str. 47.-390.

2 Uredba (EU) br. 650/2012 Europskog parlamenta i Vijeća od 4. srpnja 2012. o nadležnosti, mjerodavnom pravu, priznavanju i izvršavanju odluka i prihvaćanju i izvršavanju javnih isprava u nasljednim stvarima i o uspostavi Europske potvrde o nasljeđivanju, Službeni list EU L 201, 27. srpnja 2012., str. 107.-134.

3 Bajons, E. M., Internationale Zuständigkeit und anwendbares Recht in grenzüberschreitenden Erbrechtsfällen innerhalb des europäischen Justizraums, u: Festschrift für Andreas Heldrich zum 70. Geburtstag, Beck, 2005., str. 497.-499. 
i trećih država. ${ }^{4}$ Dominantna stajališta ipak su u korist stava da su i to treće države pa će se stoga takvima smatrati i u ovom radu.

Pravila o nadležnosti pružaju očigledno široku nadležnost nacionalnim sudovima u državama Europske unije, sve dok postoji iole neka veza s tim državama. Promjenu nadležnosti u korist trećih zemalja ne predviđaju ni odredbe o izboru suda. Pitanje je stoga zašto Uredba ne uzima u obzir dostupnost sudova trećih zemalja za korištenje jurisdikcije u skladu s vlastitim domaćim pravilima u slučajevima koji su usko povezani s takvim sudovima, gdje bi to doprinijelo u većoj mjeri za postizanje ciljeva usklađenosti i jedinstva nasljeđivanja.

Prema članku 12/1. Uredbe, ograničenje postupka pred sudom države članice, postoji samo ako je ispunjeno nekoliko uvjeta i to:

- ako ostavina sadržava imovinu koja je smještena u trećoj državi

- ako sud koji treba odlučivati o nasljeđivanju odluči da neće odlučiti o određenom dijelu te imovine

- ako takav zahtjev postavi jedna od stranaka

- te ako se sumnja da odluka u vezi s tim dijelom imovine neće biti priznata i u konačnici izvršiva u toj trećoj državi.

Dakle, čak i u situacijama za koje Uredba predviđa ograničenja postupanja na sudovima država članica, naime, kao što je rečeno, sud države članice koji vodi postupak može donijeti odluku da neće odlučivati o određenom dijelu imovine, dolazi do povrede jedinstvenog pristupa nasljeđivanju.

\section{HARMONIZACIJA NASLJEDNOG PRAVA}

Prije donošenja Uredbe o nasljeđivanju, u različitim državama Europske unije primjenjivala su se različita kolizijska pravila o nasljeđivanju. Naprimjer, neke koriste prebivalište, ali s drukčijom definicijom od one koju daju common law sustavi, a također ni korištenje poveznice državljanstva ne pridonosi izbjegavanju konfuzije. Iz pravila većine država članica Europske unije proizlazi da se zakoni o nasljeđivanju uređuju upravo na temelju državljanstva pojedinca i da je cjelokupna imovina, pokretna i nepokretna, uređena takvim zakonom. ${ }^{5}$ Osim toga, ni odluke suda, ni potvrde o nasljeđivanju jedne države, nisu bile automatski priznate i izvršive $\mathrm{u}$ drugoj državi. Razlike su često bile nepomirljive i uključivale dodatne troškove i vrijeme $\mathrm{u}$ administraciji nasljeđivanja s prekograničnim elementima u Europi. ${ }^{6}$

Usklađivanje kolizijskih pravila o nasljeđivanju prvi put je proglašeno prioritetom 1998. godine. Izvješće profesora Dörnera i Lagardea s nizom sugestija objavljeno je 2002. godine. ${ }^{7}$

4 Crawford, E. B., Carruthers, J. M., Speculation on the Operation of Succession Regulation 650/2012: Tales of the Unexpected, European Review of Private Law, vol. 22., br. 6., 2014, str. 847.-878., str. 855.; Frimston, R., The European Union Succession Regulation No. 650/2012, Estates, Trusts and Pensions Journal, vol. 33, Issue 1 (2013), str. 100.-121., str. 106.

5 Frimston, R., The European Union Succession Regulation No. 650/2012, Est. Tr. \& Pensions J., vol. 33, 2013., str. 100.-121., str. 101.

$6 \quad$ Ibid.

7 Von Bary, C., Gerichtsstands- und Schiedsvereinbarungen im internationalen Erbrecht, Mohr Siebeck, 2018., str. 12. 
Zelena knjiga o oporukama i nasljeđivanju objavljena je 2005. godine. U njoj se iznosi da Komisija pokreće javnu raspravu kako bi se riješili praktični problemi s kojima se susreću pojedinci u svezi s nasljeđivanjem i oporukom. Naime, teškoće s kojima se suočavaju osobe koje su uključene u transnacionalni sukob uglavnom proizlaze iz razlika u materijalnim pravilima, postupovnim pravilima i kolizijskim pravilima koja se primjenjuju u državama članicama. Osim toga, mobilnost pojedinaca unutar Europske unije i sve veći broj brakova između državljana različitih država članica također utječu na pitanja koja se odnose na nasljedstvo i oporučivanje. ${ }^{8}$ Nacrt Uredbe o nasljeđivanju objavljen je u listopadu 2009. godine. Najdetaljniju analizu i kritiku prvotnog nacrta vjerojatno je osigurao Max Planck institut iz Hamburga. ${ }^{9}$

Politički sporazum konačno je postignut u ožujku 2012., Uredba o nasljeđivanju donesena je 4. srpnja 2012. godine te se primjenjuje na nasljeđivanje osoba umrlih nakon 17. kolovoza 2015. godine. Kao što iz njezina naziva proizlazi, kad je riječ o nasljeđivanju sveobuhvatno uređuje nadležnost, mjerodavno pravo, priznavanje i izvršavanje odluka i prihvaćanje i izvršavanje javnih isprava te uspostavlja Europsku potvrdu o nasljeđivanju.

\section{NAČELO JEDINSTVA NASLJEĐIVANJA}

Načelo jedinstva nasljeđivanja možemo definirati u dvostrukom pogledu: s jedne strane, odnosi se na primjenu jedinstvenog zakona kod nasljeđivanja, bez obzira na prirodu imovine i bez obzira na mjesto takve imovine i, s druge strane, identitet između zakona koji uređuje nasljeđivanje i suda (ili ovlasti) koji je nadležan za njegovo vođenje. ${ }^{10}$

Iz Preambule 37. Uredbe proizlazi da bi se trebalo pobrinuti da nasljeđivanje bude uređeno pravom koje je predvidljivo i koje s njime ima blisku vezu. Da bi se osigurala pravna sigurnost i izbjegla fragmentacija nasljeđivanja, to bi pravo trebalo urediti cijelo nasljeđivanje, odnosno, svu imovinu iz ostavine, neovisno o njezinoj vrsti i tome je li smještena u drugoj državi članici Unije ili u nekoj trećoj državi.

Uredba slijedi ideju jedinstvene sheme koja u većini slučajeva omogućuje da nasljeđivanje bude podvrgnuto jednom zakonu koji će ga cjelokupno uređivati i ne dijeli pokretnu i nepokretnu imovinu, kako je prije bio slučaj u pojedinim pravima država članica. ${ }^{11} \mathrm{U}$ članku 23/1. izričito utvrđuje i načelo jedinstva prava mjerodavnog za nasljeđivanje. Ako, primjerice, osoba odabere mjerodavno pravo koje će se primjenjivati na nasljedstvo, to će se pravo morati primjenjivati na cjelokupno nasljeđivanje (čl. 22. Uredbe), djelomični izbor prava nije dopušten.

8 Succession and wills (Green Paper) [COM(2005) 65 final - Not published in the Official Journal], dostupno na: http://eur-lex. europa.eu/legal-content/EN/TXT/?uri=LEGISSUM:116017, pristupljeno 21. svibnja 2018.

9 Max Planck Institute for Comparative and International Private Law, Rabels Zeitschrift fuer auslaendisches und internationales Privatrecht, vol. 74., br. 3, 2010., str. 522.-720.

10 Popescu, D. A., Guide on international private law in successions Matters, Ministry of Justice in partnership with the National Union of Public Notaries of Romania, the German Foundation for International Legal Cooperation, the Council of Notaries of the European Union and the National Council of the Italian Notaries, 2014., str. 39.

11 Dutta, A., Succession and Wills in the Conflict of Laws on the Eve of Europeanisation, Rabels Zeitschrift fuer auslaendisches und internationales Privatrecht, vol. 73, br. 3., 2009., str. 547.-606., str. 554. 
Međutim, kada su u odnos uključene treće države, sustav može biti ugrožen stvaranjem nekoliko tijela za odlučivanje o imovini, svako podložno različitom zakonu koji potencijalno određuje nasljednike drukčije. ${ }^{12}$ Naime, do fragmentiranja nadležnosti dolazi u slučaju određivanja supsidijarne nadležnosti suda države članice Europske unije na temelju članka 10/2. Uredbe. Sukladno tom članku čak ako nijedan sud u državi članici ne bi trebao biti nadležan ni prema temeljnom, općem kriteriju uobičajenog boravišta ni prema kriteriju državljanstva države članice, sudovi države članice u kojoj je imovina ostavine imat će nadležnost, međutim oni tada mogu odlučivati samo o toj imovini, a ne o cjelokupnom nasljedstvu.

Nadalje, i u vezi s izborom mjerodavnog prava javljaju se određene nedoumice kada je u izbor uključeno pravo treće države. Postavlja se stoga pitanje može li se uopće izbor mjerodavnog prava smatrati valjanim ako unaprijed znamo da to pravo neće moći uređivati cjelokupno nasljedstvo. Kao što je rečeno, članak 22. Uredbe izričito propisuje mogućnost osobe da izabere pravo države čije državljanstvo ima u trenutku izbora ili u trenutku smrti za uređenje svoga nasljeđivanja u cijelosti. Ako tumačimo ove odredbe strogo, takav izbor prava ne bi trebao biti dopušten, budući da, u vrijeme kada je izbor učinjen, znamo da se nasljeđivanje neće voditi u cijelosti istim zakonom. No, u literaturi se iznosi da bi možda ovu odredbu ipak trebalo fleksibilnije tumačiti te u takvim situacijama dopustiti izbor prava. ${ }^{13}$

\section{NADLEŽNOST SUDOVA DRŽAVA ČLANICA}

Prema općem pravilu o nadležnosti za odlučivanje o nasljeđivanju iz članka 4. Uredbe sudovi države članice u kojoj je u trenutku smrti umrli imao uobičajeno boravište nadležni su za odlučivanje u cijelosti. Kako se, uzimajući u obzir specifične ciljeve Uredbe o nasljeđivanju, u njezinoj Preambuli 23. iznosi, uobičajeno boravište ostavitelja trebalo bi s tom državom članicom osigurati blisku i stabilnu vezu. S pomoću kriterija uobičajenog boravišta utvrđuje se nadležnost suda za rješavanje o nasljednim stvarima s prekograničnim elementom. Kao što odredba članka 2. Uredbe izrijekom predviđa, za rješavanje domaćih nasljednih stvari primjenjuju se pravila nacionalnog prava država članica. Pritom je za tumačenje kriterija prekograničnosti potrebno uzeti u obzir četiri određujuća elementa, a to su sudovi odnosno nadležna tijela, umrla osoba, nasljedstvo i nasljednici. ${ }^{14}$ Uobičajeno boravište, kao kriterij prikladan je i kada su osobe državljani više država članica, a i kada je riječ o osobama bez državljanstva. ${ }^{15}$

Izvorno je pojam uobičajenog boravišta razvijen na Haškoj konferenciji o privatnom međunarodnom pravu kao kompromis između domicilne i nacionalne pripadnosti, ali, kako bi se izbjegla krutost, nije dana njegova stroga definicija. ${ }^{16}$ Pojam uobičajenog boravišta, s obzirom na to da je pravno nedefiniran, može se procjenjivati sukladno okolnostima svakog pojedinog

\footnotetext{
12 Fuchs, A., The new EU Succession Regulation in a nutshell, ERA Forum, vol. 16, br. 2, 2015., str. 119.-124., str. 120.

13 Op. cit. Trémosa.

14 Poretti, P., Nadležnost, nadležna tijela i postupci prema Uredbi (EU) br. 650/2012 o nasljedivanju, Zbornik Pravnog fakulteta Sveučilišta Rijeka, vol. 37, br. 1, 2016., str. 561.-587., str. 565.

15 Ibid. Poretti, str. 566.; Lamont, R, Habitual Residence and Brussels II bis: Developing Concepts for European Private International Family Law, Journal of Private International Law, vol. 3, br. 2, 2007., str. 261.-281., str. 263. 
slučaja te time olakšava određivanje najprikladnijeg foruma. U praksi se međutim događalo da mu se daje različito značenje ovisno o kontekstu i svrsi, što je primjerice rezultiralo različitim tumačenjem uobičajenog boravišta djece u kontekstu roditeljske odgovornosti od uobičajenog boravišta u kontekstu razvoda, iako se oba ova pitanja rješavaju u istoj Uredbi Vijeća (EZ) br. 2201/2003 od 27. studenoga 2003. o nadležnosti, priznavanju i izvršenju sudskih odluka u bračnim sporovima i u stvarima povezanim s roditeljskom odgovornošću, kojom se stavlja izvan snage Uredba (EZ) br. 1347/2000, koju još skraćeno nazivamo i Bruxelles II bis uredba. ${ }^{17}$

Jedan od najrelevantnijih slučajeva u vezi s definicijom uobičajenog boravišta bavio se pitanjima socijalnog osiguranja. ${ }^{18} \mathrm{U}$ tom je predmetu Sud Europske unije pružio odgovarajući test za utvrđivanje uobičajenog boravišta i opisao kada osoba ima uobičajeno boravište u državi članici. ${ }^{19}$ Prema toj presudi, osoba stalno boravi u državi članici kada se u njoj nalazi njezino uobičajeno središte interesa, zatim se u obzir uzimaju dužina i kontinuitet boravka, okolnost da je u njoj zaposlena, obiteljski status te bi u takvom mjestu trebao biti prisutan i dokazan određeni element rutine. ${ }^{20}$

Radi utvrđivanja uobičajenog boravišta, sukladno Preambuli 23. Uredbe o nasljeđivanju, "tijelo koje se bavi nasljeđivanjem trebalo bi izvršiti ukupnu procjenu životnih okolnosti umrlog tijekom posljednjih godina njegova života i u trenutku smrti, uzimajući u obzir sve relevantne činjenične elemente, posebno trajanje i stalnost prisutnosti umrlog u dotičnoj državi te uvjete i razloge za tu prisutnost. Tako utvrđeno uobičajeno boravište trebalo bi imati blisku i stabilnu vezu s dotičnom državom, uzimajući u obzir konkretne ciljeve ove Uredbe." Pojam uobičajeno boravište u literaturi najčešće podrazumijeva razdoblje tijekom kojeg je pojedinac prisutan u državi dovoljno dugo da se njegova nazočnost ondje smatra rutinskom. Stanovanje u razdoblju od godinu dana u pravilu se smatra dovoljnim za uobičajeno boravište jer ukazuje na neku integraciju u to društvo. ${ }^{21}$

Utvrđivanje uobičajenog boravišta umrlog u nekim bi se slučajevima katkad moglo pokazati još složenijim, prije svega onda kada se umrli tijekom duljeg razdoblje, zbog razloga profesionalne ili ekonomske prirode, odselio u inozemstvo, međutim i dalje zadržavši blisku i stabilnu vezu s državom iz koje potječe. U takvim slučajima, u Preambuli 24. iznosi se da bi se moglo i "dalje smatrati, ovisno o okolnostima slučaja, da je umrli imao svoje uobičajeno boravište u svojoj državi podrijetla u kojoj je bilo središte interesa njegove obitelji i njegov društveni život. Drugi složeni slučajevi mogu se pojaviti ako je umrli živio u nekoliko država naizmjence ili ako je putovao iz jedne države u drugu a da se nije stalno nastanio u bilo kojoj od njih. Ako je umrli bio državljanin jedne od tih država ili ako je imao svu svoju glavnu imovinu u jednoj

17 Vidjeti Uredbu Vijeća (EZ) br. 2201/2003 od 27. studenoga 2003. o nadležnosti, priznavanju i izvršenju sudskih odluka u bračnim sporovima i u stvarima povezanim s roditeljskom odgovornošću, kojom se stavlja izvan snage Uredba (EZ) br. 1347/2000., OJ L 338, 23. prosinca 2003., str. 1.-29.; Ibid. Clarkson, str. 330.; više vidjeti: Beaumont, P., Holliday, J., Recent developments on the meaning of "habitual residence" in alleged child abduction cases; dostupno na: https://www.abdn.ac.uk/law/documents/RecentDevelopments-on-the-Meaning-of-Habitual-Residence-in-Alleged-Child-Abduction-Cases-pdf, pristupljeno: 18. svibnja 2018. vidi također: Case Mercredi C-497/10 PPU i case C v. M C-376/14 PPU. Case Robert Swaddling v. Adjudication officer C-90/97, 25. veljače 1999.

19 Lamont, R., Habitual residence and Brussels II bis: developing concepts for European private international family law, Journal of Private International Law, vol. 3, br. 2, 2007., str. 265.

20 Op.cit. u bilj. 18, par. 29. 
od tih država, državljanstvo ili mjesto te imovine mogli bi biti poseban čimbenik u ukupnoj procjeni svih činjeničnih okolnosti" (Preambula 24. Uredbe).

U nekim je okolnostima poželjno da se radi zaštite pojedince i sprječavanja praznina u nadležnosti uobičajeno boravište što brže uspostavi. Želja za uspostavljanjem uobičajenog boravka nakon vrlo kratkog razdoblja znači da je namjera pojedinca u prebivalištu postala relevantna glede njihova stalnog boravka. U tom će se slučaju morati odmjeriti odnos duljine prebivanja sa željom, odnosno namjerom prebivanja u određenom mjestu. Dakle pri tom će utvrđivanju, što je kraće razdoblje prebivanja, pitanje namjere biti važnije. ${ }^{22}$

Koncept uobičajenog boravišta stoga je vrlo pogodan u suvremenom svijetu u kojem je postalo mnogo lakše putovati i kretati se, posebice u kontekstu Europske unije, budući da ovaj koncept uspijeva identificirati zemlju s kojom je ta osoba imala blisku i legitimnu povezanost u relativno novijem razdoblju svog života, iako bi neka druga naočigled bliža veza mogla povezati osobu u pitanju s nekom drugom državom. ${ }^{23}$

\subsection{SUPSIDIJARNA NADLEŽNOST SUDA DRŽAVE ČLANICE EUROPSKE UNIJE I FORUM NECESSITATIS}

Odstupanje od određivanja nadležnosti na temelju kriterija uobičajenog boravišta nalazimo u članku 10. Uredbe o nasljeđivanju. Ako je ostavitelj svoje posljednje uobičajeno boravište imao u državi koja nije članica Europske unije, dakle trećoj državi, tada članak 10. propisuje supsidijarnu nadležnost suda države članice. Na temelju tog članka, stavka 1. sudovi države članice u kojoj je (bilo kakva) imovina ostavine i dalje će u potpunosti imati nadležnost za odlučivanje o nasljeđivanju pod uvjetom da je u trenutku smrti umrli bio državljanin te države članice. Ako taj uvjet nije ispunjen, ti će sudovi i dalje biti nadležni, ako je u toj državi članici umrli imao svoje prethodno uobičajeno boravište, ali pod uvjetom da u trenutku pokretanja postupka nije proteklo više od pet godina od promjene tog uobičajenog boravišta. Nadalje, čak ako nijedan sud u državi članici nema nadležnost sukladno navedenim uvjetima, prema stavku 2. istog članka, sudovi države članice u kojoj je neka imovina ostavine i dalje imaju nadležnost, međutim oni tada mogu odlučivati samo o toj imovini, ne o cjelokupnom nasljedstvu.

Supsidijarna nadležnosti koja se predviđa u članku 10/1. u skladu je s ciljem očuvanja jedinstva nasljeđivanja, budući da predviđa opću nadležnost koja će se proširiti na nasljeđivanje u cjelini, baš kao i temeljni kriterij uobičajenog boravišta iz članka 4. Uredbe. Isto se, međutim, ne događa u vezi s kriterijem na temelju članka 10/2., koji, naprotiv, propisuje nadležnost koja je ograničena samo na imovinu koja se nalazi na području države članice suda. ${ }^{24}$

Ovakvo rješenje usvojeno u Uredbi o nasljeđivanju u tom pogledu vjerojatno će dovesti do čestih slučajeva istodobnih postupaka između sudova država članica i sudova trećih zema-

22 Rogerson, P., Habitual Residence: The New Domicile? International and Comparative Law Quarterly, vol. 49, 2000., str. 86.-107., str. 96.

23 Op. cit. Clarkson C., Hill, J., str. 341.

24 Bonomi, A., Article 10, u: Bonomi, A., Wautelet, P. (eds), Le droit européen des successions. Commentaire du règlement $\mathrm{n}^{\circ}$ 650/2012 du 4 juillet 2012, Bruylant, 2013., str. 213.-223. 
lja. Postavlja se stoga pitanje zašto poraziti jedinstvo nasljeđivanja ostvarivanjem nadležnosti ograničene na imovinu koja se nalazi na teritoriju dotične države članice bez mogućnosti da se uzme u obzir mogućnost sudova neke treće zemlje s kojima je nasljeđivanje više povezano te je na raspolaganju za provođenje svoje nadležnosti u vezi s nasljeđivanjem u cjelini? ${ }^{25}$

Konačno, u članku 11. Uredba predviđa da čak i u slučaju da se nadležnost sudova država članica ne može ostvariti ni prema jednom od navedenih kriterija "sudovi države članice, u iznimnim slučajevima, mogu odlučivati o nasljeđivanju ako u trećoj državi s kojom je slučaj usko povezan postupak nije moguće pokrenuti ili provesti u razumnim okvirima ili postupak u trećoj državi nije moguć (forum necessitatis). Slučaj mora u dovoljnoj mjeri biti povezan s državom članicom suda pred kojim je pokrenut postupak."

\section{IZBOR MJERODAVNOG PRAVA I NADLEŽNOG SUDA}

Pravo mjerodavno za nasljeđivanje u cijelosti sukladno članku 21. Uredbe pravo je države u kojoj je umrli u trenutku svoje smrti imao uobičajeno boravište. Osoba na temelju odredbe članka 22. Uredbe ima pravo izabrati i drugo pravo koje će u cijelost uređivati njezino nasljeđivanje i to, kako bi se između izabranog prava i umrlog osigurala veza, pravo države čiji je državljanin u trenutku izbora ili u trenutku smrti. Nije moguće odabrati pravo koji se primjenjuje samo na dio nasljedstva jer bi to bilo suprotno cilju Uredbe, koji je osiguranje da jedan i isti zakon uređuje cjelokupno nasljeđivanje.

Što se izbora suda tiče, neovisno o tome je li bilo koji sud u državi članici nadležan na temelju članaka 4. i 10. Uredbe, sukladno članku 5. Uredbe moguće je da stranke na koje se to odnosi sporazumno izaberu sud, ali samo ako je pravo koje je za uređenje svojeg nasljeđivanja umrli izabrao, pravo države članice čije je državljanstvo imao u trenutku izbora ili smrti (čl. 22. Uredbe). Sporazum o izboru suda mora biti pisan i s potpisima stranaka na koje se odnosi. Jednakovrijednom pisanu obliku smatra se i svako priopćenje elektroničkim sredstvima s trajnim zapisom (čl. 5/2. Uredbe). Prorogacija sukladno članku 9. može biti i prešutna.

Osim što članak 5. Uredbe izričito dopušta izbor nadležnog suda samo kada je umrli izabrao pravo države članice tog suda, iz članka 6. proizlazi da sudovi država članica mogu otkloniti svoju nadležnost u slučaju izbora prava samo u ovoj odredbi izričito predviđenim okolnostima. Prema tome, sud pred kojim je postupak pokrenut sukladno člancima 4. ili 10. Uredbe, može, temeljem zahtjeva jedne od stranaka u postupku, odbiti svoju nadležnost. On će to moći učiniti "ako smatra da su sudovi države članice izabranog prava u boljem položaju odlučivati o nasljeđivanju, uzimajući u obzir praktične okolnosti nasljeđivanja, poput uobičajenog boravišta stranaka i mjesta gdje se imovina nalazi; ili odbija nadležnost ako su se stranke u postupku sporazumjele, u skladu s člankom 5., o prenošenju nadležnosti na sud ili sudove države članice izabranog prava" (čl. 6. Uredbe).

U vezi s pitanjem prava izbora suda treće države iz odredbi članka 5. i 22. Uredbe posve jasno proizlazi da ta mogućnost nije predviđena. Stoga, ako je umrli izabrao pravo treće države 
čiji je državljanin, u tom slučaju neće se moći izvršiti izbor suda te države. Ove odredbe omogućavaju izbor suda samo u državi članici u kojoj je umrli bio državljanin, pod uvjetom da je odredio nacionalni zakon te države kao zakon koji je mjerodavan za uređenje njegova nasljeđivanja. Kao što je rečeno, prema općem pravilu o nadležnosti iz članka 4. Uredbe sudovi države članice u kojoj je umrli u trenutku smrti imao svoje uobičajeno boravište, imaju nadležnost odlučivati o nasljeđivanju u cijelosti. Iz odredbi jasno proizlazi da, državljaninu treće države i zainteresiranim strankama, za razliku od slučajeva kada je pokojnik imao državljanstvo države članice i za uređenje svojeg nasljeđivanja izabrao pravo države članice čije je državljanstvo imao u trenutku izbora ili smrti, članak 5. Uredbe ne dopušta da se odluče za nadležnost suda treće države, budući da ta država nije država članica. Prema tome, u tim slučajevima stranke neće moći uspostaviti nadležnost u korist zakona nacionalnosti ostavitelja.

Na primjeru državljanina Republike Bosne i Hercegovine koji stalno boravi u Republici Hrvatskoj bi to, prema općem pravilu Uredbe o nasljeđivanju (čl. 4. Uredbe), značilo da će za njegovo cjelokupno nasljeđivanje biti nadležan sud Republike Hrvatske. Ako on u oporuci izrazi želju da se kao mjerodavno pravo za njegovo nasljeđivanje uzme nacionalno pravo Bosne i Hercegovine, sud u Republici Hrvatskoj i dalje će biti nadležan, bez mogućnosti prorogacije nadležnosti izborom suda Bosne i Hercegovine (arg. ex. čl. 5. i 22. Uredbe). Mjesna nadležnost općinskog suda u Republici Hrvatskoj sukladno članku 3. Zakona o provedbi Uredbe (EU) br. 650/2012 Europskog parlamenta i Vijeća od 4. srpnja 2012. o nadležnosti, mjerodavnom pravu, priznavanju i izvršavanju odluka i prihvaćanju i izvršavanju javnih isprava u nasljednim stvarima i o uspostavi europske potvrde o nasljeđivanju ${ }^{26}$ za provođenje tog ostavinskog postupka odredit će se primjenom odredaba hrvatskog Zakona o nasljeđivanju, pa će u tom slučaju mjesnu nadležnost imati sud na čijem je području ostavitelj u trenutku smrti imao prebivalište, odnosno boravište, ako u vrijeme smrti nije imao prebivalište u Republici Hrvatskoj (čl. 177. st. 1. i 2. ZN-a).

Međutim, ako taj državljanin Bosne i Hercegovine, ima imovinu i u nekoj drugoj državi nečlanici Europske unije, na tu bi se imovinu, sukladno njezinim pozitivnim propisima, moglo primijeniti pravo te države. U navedenom primjeru, stoga, iako je kao mjerodavno izabrano nacionalno pravo umrloga, nasljeđivanje u cjelini neće biti uređeno jednim istim zakonom pa bi radi pravne sigurnosti, za imovinu koja se nalazi na teritoriju treće države, trebalo sastaviti posebnu oporuku sukladno pozitivnim propisima te države. Iako bi do iste situacije došlo da izbor prava i nije bio učinjen, naime, sukladno Uredbi, na nasljeđivanje bi se primijenilo pravo države članice Europske unije prema uobičajenom boravištu umrloga, međutim, za imovinu u trećoj državi, ovisno o pozitivnim propisima te države, u njoj bi se na tu imovinu primijenilo njezino pravo, s obzirom na cilj odredbe o izboru prava (osiguranje da jedan i isti zakon uređuje cjelokupno nasljeđivanje), postavlja se pitanje hoće li takav izbor prava, budući da se ne odnosi na nasljedstvo u cijelosti, biti valjan. ${ }^{27}$ Javni bilježnici ili druge ovlaštene osobe u takvim će slučajevima imati važnu dužnost davati savjete, naime moraju skrenuti pozornost klijentu na mogući rizik da će izbor zakona možda biti smatran nevaljanim i na određeni rizik da će

26 Zakon o provedbi Uredbe (EU) br. 650/2012 Europskog parlamenta i Vijeća od 4. srpnja 2012. o nadležnosti, mjerodavnom pravu, priznavanju i izvršavanju odluka i prihvaćanju i izvršavanju javnih isprava u nasljednim stvarima i o uspostavi europske potvrde o nasljeđivanju, Narodne novine, broj 152/2014.

27 Trémosa, F., The state of implementation of the EU Succession Regulation's provisions on its scope, applicable law, freedom of choice, and parallelism between the law and the courts, 2017., str. 6., dostupno na: www.europarl.europa.eu/studies, pristupljeno 15. svibnja 2018. 
nasljedstvo biti fragmentirano. Stoga moraju savjetovati svom klijentu da poduzme mjere koje su kompatibilne s tim dvostrukim rizikom. ${ }^{28}$

S druge strane, državljanin Republike Slovenije koji stalno boravi u Republici Hrvatskoj, osim što može kao mjerodavno pravo izabrati pravo svog državljanstva, njegovi će nasljednici moći izabrati i nadležnost slovenskog suda. O eventualnom ograničenju postupanja pred sudom države članice, u smislu da ako se ostavina umrlog sastoji od imovine koja se nalazi u trećoj državi vidjeti više infra.

U pravnoj se literaturi u vezi s ograničenjem privatne autonomije stranaka u postupku postavljenih u pravilima o prorogaciji nadležnosti, iznosi niz kritika. Prije svega to su kritike što se stranke u postupku inter partes mogu samo u slučaju da je ostavitelj prethodno učinio izbor mjerodavnog prava sporazumjeti o nadležnosti, a i tada samo u odnosu na sudove države članice čije je pravo ostavitelj izabrao. ${ }^{29}$ Dutta tako kritizira europskog zakonodavca jer privatnu autonomiju dopušta samo ako od sudova otklanja primjenu stranog prava te time usklađenost nadležnog suda i prava izdiže na štetu postupovnih stranaka, kojima su nedostaci primjene stranog prava samo jedan od niza čimbenika koji utječu na njihov izbor suda. Zbog toga smatra da bi se čl. 5. Uredbe o nasljeđivanju trebao tumačiti što je šire moguće. ${ }^{30}$

Osim nemogućnosti prorogiranja nadležnosti na sudove trećih država, u literaturi se iznosi da odredbe o prorogaciji sadrže još jedno značajno okrnjenje stranačke autonomije: naime, ostavitelju nije pružena mogućnost jednostranog izbora nadležnog suda za odlučivanje o njegovoj ostavini. ${ }^{31} \mathrm{Da}$ bi iole utjecao na nadležnost, ostavitelj u najboljem slučaju može, u okviru ugovora o nasljeđivanju s budućim strankama u postupku, zaključiti sporazum o nadležnosti. Međutim, u procesnopravnom smislu, ostavitelj u tom slučaju ne može spriječiti stranke koje sudjeluju u postupku da isti sporazum naknadno ponište. ${ }^{32}$

\section{OGRANIČENJE POSTUPKA PRED SUDOM DRŽAVE ČLANICE}

Ograničenje postupka pred sudom države članice, u smislu da "ako se ostavina umrlog sastoji od imovine smještene u trećoj državi, sud koji treba odlučiti o nasljeđivanju može, na zahtjev jedne od stranaka, odlučiti da neće odlučiti o nekom dijelu te imovine ako se može očekivati da njegova odluka u pogledu tog dijela imovine neće biti priznata i, prema potrebi, proglašena izvršivom u toj trećoj državi”, propisuje članak 12/1. U stavku 2. tog članka iznosi se da to ne zadire u "pravo stranaka da ograniče opseg postupka po pravu države članice suda pred kojim je postupak pokrenut." Članak 12/1. propisuje dakle da ako su ispunjeni uvjeti, sud

28 Ibid.

29 Dutta, A., Novo međunarodno nasljedno pravo Evropske unije - prvo čitanje Uredbe o nasljednom pravu, Nova pravna revija, Sarajevo, vol. 2, 2013., str. 9.-22., str. 12.

30 Ibid.

31 Ibid.

32 Ibid.; vidjeti također: Comments on the European Commission's Proposal for a Regulation of the European Parliament and of the Council on jurisdiction, applicable law, recognition and enforcement of decisions and authentic instruments in matters of succession and the creation of a European Certificate of Succession, Rabels Zeitschrift für ausländisches und internationales Privatrecht, vol. 74, 2010. , str. 522.-720., str. 586. 
može odlučiti da ne donese odluka o imovini koja se nalazi u trećoj državi. Posljedično, predmet ograničenja nije nadležnost suda, nego predmet postupka.

Očito je stoga da čak i u rijetkim situacijama za koje Uredba predviđa ograničenja postupanja na sudovima država članica, dolazi do odstupanja od načela jedinstvenog pristupa nasljeđivanju jer sud države članice koji vodi postupak može odlučiti da neće donositi odluku o nekom dijelu imovine. Sudovi države članice ostaju i tada nadležni za odlučivanje o imovini koja se nalazi u trećoj državi, ali mogu izabrati da to ne čine. Ograničenje stoga nije obvezatno, nego je prepušteno diskrecijskoj ocjeni suda.

\subsection{UVJET NEPRIZNAVANJA ILI NEIZVRŠAVANJA ODLUKE}

Svrha članka 12/1. Uredbe o nasljeđivanju pronalazi se u uvjetu nepriznavanja ili neizvršavanja odluke u trećoj državi. Glavni razlog za takvo uskraćivanje priznanja i izvršenja u trećoj državi jest da će te države svoje sudove smatrati isključivo nadležnim za odlučivanje u sporu koji se odnosi na nepokretnu imovinu koja se nalazi na njezinu teritoriju i stoga sudovi svih drugih država nisu nadležni.

Naime, iako Uredba regulira nasljeđivanje u cjelini, bez obzira na prirodu imovine, odnosno na to je li pokretna ili nepokretna (čl. 23/1. Uredbe), pravni sustavi mnogih država prave razliku u primjeni prava prije svega kada je posrijedi nepokretna imovina. Primjerice, posebna pravila o stjecanju nekretnina stranaca mogla su se naći i u hrvatskom Zakonu o zaštiti prirode iz 2005. godine ${ }^{33}$ koji je zabranjivao stjecanje nekretnina u posebno reguliranim dijelovima prirode kao što su nacionalni parkovi, stroge rezerve, parkovi prirode itd. Nakon ulaska Republike Hrvatske u Europsku uniju 1. srpnja 2013. godine, dana 6. srpnja 2013. stupio je na snagu novi Zakon o zaštiti prirode. ${ }^{34}$ Njime je ukinuta zabrana stjecanja vlasništva nad nekretninama u zaštićenim prirodnim područjima za strane državljane ili pravne osobe. Ali se primjerice u Turskoj, koja nije članica Europske unije, primjenjuju različita pravila za nekretnine unutar ili izvan Turske. Prema turskom pravu nasljeđivanje podliježe nacionalnom zakonu ostavitelja, međutim, nekretnine koje se nalaze u Turskoj bit će podložne samo turskom materijalnom pravu. Ako se nekretnine nalaze izvan Turske, ta će imovina biti podložna nacionalnom zakonu ostavitelja. ${ }^{35}$

Ipak, tekst odredbe čini se da je preširok da bi se ograničio na taj jedini razlog za nepriznavanje te sugerira da pokriva i druge razloge, poput izravnog odbijanja ove države da prizna bilo kakvu stranu presudu, nepostojanje uzajamnosti, odbijanje te države da prizna neizravnu nadležnost sudova pred kojim se postupak vodi na temelju Uredbe, sukobu s prethodno donesenom presudom (res judicata) ili presudom koja je u tijeku ili čak suprotnost presude s javnim

Zakon o zaštiti prirode, Narodne novine, broj 80/2013. 
poretkom te treće države. ${ }^{36}$ Tako primjerice i hrvatski Zakon o nasljeđivanju ${ }^{37}$ zahtijeva uzajamnost kada je posrijedi pravo stranaca na nasljeđivanje. Ta se uzajamnost pretpostavlja sve dok se ne dokaže suprotno (članak 2/2. Zakona o nasljeđivanju) pa je tako izrekao i Vrhovni sud Republike Hrvatske. ${ }^{38}$

Zanimljiv slučaj dokazivanja uzajamnosti i njezina odnosa prema pravu na pravično suđenje našao se pred Ustavnim sudom Republike Hrvatske 2004. godine. ${ }^{39}$ Predmet se odnosio na podnositelja zahtjeva koji je bio državljanin Kraljevine Jordana i koji je trebao naslijediti neku imovinu u predmetu koji je doveo pred hrvatski sud. Sud je zatražio izjavu Ministarstva pravosuđa o pitanjima uzajamnosti u nasljeđivanju između Jordana i Republike Hrvatske koju nije dobio, iako je tražena u više navrata. Ustavni sud je utvrdio da je podnositelju zahtjeva povrijeđeno pravo na pošteno suđenje i dodijeljena mu je naknada. ${ }^{40} \mathrm{Iz}$ predmeta je nejasno zašto je odbijena uzajamnost, međutim, predmet pokazuje kako zahtjev uzajamnosti može uzrokovati nepotrebne teškoće. ${ }^{41}$ Sada, kao država članica Europske unije, Hrvatska zahtjev uzajamnosti više ne može postavljati prema građanima Europske unije, ${ }^{42}$ budući da njihov procesni položaj treba biti jednak onome domaćih građana. ${ }^{43}$

Ipak, kada govorimo o članku 12. Uredbe, nijedan od tih razloga ne bi smio utjecati na njegovu primjenu. Poricanje treće države da uopće prizna bilo kakvu stranu presudu, kao i ekvivalentni razlog nedostatka uzajamnosti, pitanja su političke prirode koja, u nedostatku jasne i izričite zakonske odredbe, ne bi smjela biti prepuštena diskreciji sudova. ${ }^{44}$

Nadalje, sud pred kojim se vodi postupak ne bi trebao ispitivati vjerojatnost nepriznavanja na temelju činjenice da već postoji odluka suda treće države u kojoj se nalazi imovina u pitanje ili na temelju postupka koji u toj državi teče. Razlog tomu jest što su res judicata i postupci pokrenuti u trećoj državi izvan opsega ove Uredbe. ${ }^{45}$

\section{ZAKLJUČAK}

Očito je da se, u slučajevima povezanim s trećim državama, uspostavljanje podudarnosti između nadležnosti i mjerodavnog prava može pokazati nemogućim, budući da raspodjela

36 Panopoulos, G., Limitation of Proceedings under Article 12 Successions Regulation (2012) - An Impossible Codification of the Improbable, Elte Law Journal, vol. 2015, br. 2, 2015., str. 99.-108., str. 103.

37 Zakon o nasljeđivanju, Narodne novine, broj 48/2003, 163/2003, 35/2005, 127/2013, 33/2015.

38 Presuda Vrhovnog suda Republike Hrvatske Rev 3341/1993-2 od 23. lipnja 1994.

39 Presuda Ustavnog suda Republike Hrvatske U-IIIA/1335/2004 od 8. prosinca 2004.

40 Ibid.

41 Ratković, T., Private International Law Aspects of Succession - The Croatian Experience, Annals of the Faculty of Law of the University of Zenica, vol. 13, 2014., str. 8.-33., str. 10.

42 Unutar područja primjene ugovorâ i ne dovodeći u pitanje bilo koju njihovu posebnu odredbu, zabranjena je svaka diskriminacija na temelju državljanstva (članak 18/1. Ugovora o funkcioniranju Europske unije).

Op. cit. Ratković. 
nadležnosti među sudovima država članica sukladno Uredbi o nasljeđivanju ne uzima u obzir mogućnost da u takvim slučajevima imaju nadležnost sudovi trećih zemalja s kojim nasljeđivanje ostvaruje značajnu povezanost. Zapravo, Uredba o nasljeđivanju pobrinula se samo za obrnuti scenarij, nemogućnosti sudova treće države da se bave slučajem, osiguravajući nadležnost sudova države članice koja s istim ima dovoljno veze. Naime, ako, unatoč opsežnoj jurisdikciji koja se priznaje u odnosu na sudove država članica, takav sud nije nadležan prema navedenim pravilima, sud države članice može i dalje iznimno biti nadležan na temelju članka 11. (forum necessitatis), ako u trećoj državi, s kojom slučaj ima usku povezanost, postupak nije moguće u razumnim okvirima pokrenuti ili provesti ili postupak uopće nije moguć. Slučaj ipak mora u dovoljnoj mjeri biti povezan s državom članicom suda pred kojim je pokrenut postupak.

Iz Preambule 37. Uredbe proizlazi važnost osiguranja da nasljeđivanje uređuje blisko povezano i predvidljivo pravo. To bi pravo, radi pravne sigurnosti i izbjegavanja fragmentacije nasljeđivanja, trebalo uređivati nasljeđivanje u cjelini, to jest, svu imovinu koja čini ostavinu, bez obzira na njezinu vrstu i na to gdje je smještena, bilo to u drugoj državni članici ili u nekoj trećoj državi. Stoga, u konačnici, rješenja koja se predlažu u ovom radu odnose se na izmjenu članka 5. i s njim u svezi članka 6. Uredbe o nasljeđivanju u vezi sa slučajevima kada je pravo, koje je izabrao umrli sukladno članku 22. Uredbe, pravo treće države. Izmijenjene, te bi odredbe trebale strankama kojih se tiču omogućiti da se sporazume da su sudovi trećih država odabranog prava i nadležni za rješavanje nasljeđivanja te dopustiti sudovima država članica da odbace svoju nadležnost in favorem sudova trećih država, pod uvjetom da su ti sudovi tada nadležni za odlučivanje o nasljeđivanju u cjelini. ${ }^{46}$ Osim toga, radi jačanja pravnog položaja i autonomije osobe o čijoj je ostavini uopće riječ - ostavitelj bi trebao imati mogućnost izbora nadležnog suda države svog državljanstva koji će odlučivati o pitanjima nasljeđivanja njegove ostavine. Izbor bi, jednako kao i kada je riječ o sporazumu stranaka kojih se tiče, trebao biti moguć kako u odnosu na sudove država članica, tako i u odnosu na treće države te također pod uvjetom da su ti sudovi tada nadležni za odlučivanje o nasljeđivanju u cjelini.

Kako bi se osigurala što veća razina ujednačenosti u tretiranju trećih država u odnosu na države članice Unije, u Uredbu bi, Marongiu Buonaiuti predlaže, a s čime bismo se mogli složiti, trebala također biti uvedena posebna pravila o priznavanju i izvršenju odluka o nasljeđivanju koja su donijeli sudovi trećih država. Ovakvo rješenje bi, umjesto ostvarivanja nadležnosti ograničene na imovinu koja se nalazi na teritoriju države članice, bez uzimanja u obzir mogućnosti suda treće zemlje s kojima je nasljeđivanje povezanije te je na raspolaganju za provođenje svoje nadležnosti glede nasljeđivanja u cjelini, spriječilo provođenje istodobnih postupaka na sudovima država članica i sudovima trećih zemalja te bi pridonijelo ostvarenju jedinstva nasljeđivanja. Vjerojatno bi takva pravila ipak trebala osigurati i dodatne uvjete, $u$ odnosu na postojeće propise o priznavanju presuda država članica, barem kako bi se osigurala postojeća dostatna veza između nasljeđivanja i treće države čiji su sudovi donijeli presudu za priznavanje. ${ }^{47}$ Zapravo, iako je, prema načelu međusobnog povjerenja, dosad općeprihvaćeno da, među državama članicama, nije dopušteno preispitivanje merituma u fazi priznavanja i izvršenja (čl. 41. Uredbe o nasljeđivanju), takvo bi preispitivanje i dalje bilo poželjno u vezi s

46 Marongiu Buonaiuti, F., The EU Succession Regulation and third country courts, Journal of Private International Law, vol. 12, br. 3, 2016., str. 545.-565., str. 564 . 
odlukama koje donose sudovi trećih zemalja. ${ }^{48}$ Radi dosljednosti, navedena bi pravila trebala spriječiti oslanjanje pojedinih država članica na njihova vlastita neizravna pravila o nadležnosti za priznavanje i izvršenje odluka sudova trećih zemalja u pitanjima nasljeđivanja. Uvođenje predloženih izmjena i dopuna pomoglo bi u potpunoj koordinaciji s nadležnostima sudova iz trećih zemalja više nego što je dosad postignuto prilično izoliranim mehanizmom predviđenim člankom 12. Uredbe o nasljeđivanju. ${ }^{49}$ Svrha tog članka pronalazi se u uvjetu nepriznavanja ili neizvršavanja odluke u trećoj državi. Međutim, iako članak 59/1. točka 1. Uredbe o nasljeđivanju nalaže da javna isprava sastavljena u državi članici u drugoj državi članici u pravilu ima istu formalnu dokaznu snagu ili najsličniji učinak, kao u državi porijekla, ipak, ni ta odluka donesena u državi članici ne mora biti nužno priznata i za to se u Uredbi navode razlozi, ${ }^{50}$ i ono što je najznačajnije, to ne predstavlja formalno ograničenje nadležnosti. Stoga ni nakon detaljne analize odredbi Uredbe nije posve shvatljivo zašto je potrebno jedno takvo ograničavanje u postupanju koje ispitivanje nadležnosti dodatno tereti i s predviđanjem hoće li u trećoj državi odluka biti priznata ili ne. Svakoj od stranaka trebalo bi biti prepušteno odlučivanje hoće li ili neće odluku donesenu u državi članici primjenjivati u trećoj državi, a pozvani bi se sud u tim slučajevima trebao suzdržano koristiti svojim pravom na diskrecijsku ocjenu. ${ }^{51}$

\section{LITERATURA, PROPISI I SUDSKE ODLUKE}

1. Bajons, E. M., Internationale Zuständigkeit und anwendbares Recht in grenzüberschreitenden Erbrechtsfällen innerhalb des europäischen Justizraums, u: Festschrift für Andreas Heldrich zum 70. Geburtstag, Beck, 2005., str. 497.-499.

2. Crawford, E. B., Carruthers, J. M., Speculation on the Operation of Succession Regulation 650/2012: Tales of the Unexpected, European Review of Private Law, vol. 22, br. 6, 2014., str. 847.-878.

3. Frimston, R., The European Union Succession Regulation No. 650/2012, Estates, Trusts and Pensions Journal, vol. 33, br. 1, 2013., str. 100.-121.

4. Frimston, R., The European Union Succession Regulation No. 650/2012, 33 Est. Tr. \& Pensions J., vol. 33, 2013., str. 100.-121.

5. Von Bary, C., Gerichtsstands- und Schiedsvereinbarungen im internationalen Erbrecht, Mohr Siebeck, 2018.

6. Max Planck Institute for Comparative and International Private Law, Rabels Zeitschrift fuer auslaendisches und internationales Privatrecht, vol. 74, br. 3, 2010., str. 522.-720.

7. Popescu, D. A., Guide on international private law in successions Matters, Ministry of Justice in partnership with the National Union of Public Notaries of Romania, the German Foundation for International Legal Cooperation, the Council of Notaries of the European Union and the National Council of the Italian Notaries, 2014.

8. Dutta, A., Succession and Wills in the Conflict of Laws on the Eve of Europeanisation, Rabels Zeitschrift fuer auslaendisches und internationales Privatrecht, vol. 73, br. 3, 2009., str. 547.-606.

48 Više vidjeti: Weller, M., Mutual trust: in search of the future of European Union private international law, Journal of Private International Law, vol. 64, 2015., str. 82.-90.

49 Op. cit. Marongiu Buonaiuti.

50 Vidjeti čl. 40. Uredbe o nasljeđivanju.

51 Op. cit. Dotta, str. 13 
9. Fuchs, A., The new EU Succession Regulation in a nutshell, ERA Forum, vol. 16, br. 2, 2015., str. 119.-124.

10. Poretti, P., Nadležnost, nadležna tijela i postupci prema Uredbi (EU) br. 650/2012 o nasljeđivanju, Zbornik Pravnog fakulteta Sveučilišta Rijeka, vol. 37, br. 1, 2016., 561.-587.

11. Lamont, R, Habitual Residence and Brussels II bis: Developing Concepts for European Private International Family Law, Journal of Private International Law, vol. 3, br. 2, 2007., str. 261.-281.

12. Clarkson, C., Hill, J., The Conflict of Laws, New York, Oxford University Press, 2011.

13. Beaumont, P., Holliday, J., Recent developments on the meaning of "habitual residence" in alleged child abduction cases; dostupno na: https://www.abdn.ac.uk/ law/documents/Recent-Developments-on-the-Meaning-of-Habitual-Residence-in-Alleged-Child-Abduction-Cases-pdf, pristupljeno: 18. svibnja 2018.

14. Lamont, R. Habitual residence and Brussels II bis: developing concepts for European private international family law, Journal of Private International Law, vol. 3, br. 2, 2007.

15. Clive, E., The Concept of Habitual Residence, Juridical Review, part 3, 1997.

16. Rogerson, P., Habitual Residence: The New Domicile? International and Comparative Law Quarterly, vol. 49, 2000., str. 86.-107.

17. Bonomi, A., Article 10, u: Bonomi, A.,Wautelet, P., (eds), Le droit européen des successions. Commentaire du règlement $n^{\circ}$ 650/2012 du 4 juillet 2012, Bruylant, 2013., str. 213.-223.

18. Trémosa, F., The state of implementation of the EU Succession Regulation's provisions on its scope, applicable law, freedom of choice, and parallelism between the law and the courts, 2017., str. 6., dostupno na: www.europarl.europa.eu/studies, pristupljeno: 15. svibnja 2018.

19. Dutta, A., Novo međunarodno nasljedno pravo Evropske unije - prvo čitanje Uredbe o nasljednom pravu, Nova pravna revija, Sarajevo, 2/2013., str. 9.-22.

20. Comments on the European Commission's Proposal for a Regulation of the European Parliament and of the Council on jurisdiction, applicable law, recognition and enforcement of decisions and authentic instruments in matters of succession and the creation of a European Certificate of Succession, Rabels Zeitschrift für ausländisches und internationales Privatrecht, vol. 74, 2010., str. 522.-720.

21. Tekinalp, G., Nomer, E., Odman Boztosun, A., Private International Law in Turkey, Wolters Kluwer, Netherland, 2012.

22. Panopoulos, G., Limitation of Proceedings under Article 12 Successions Regulation (2012)-An Impossible Codification of the Improbable, ELTE Law journal, vol. 2015, br. 2, 2015., str. 99.-108.

23. Ratković, T., Private International Law Aspects of Succession - The Croatian Experience, Annals of the Faculty of Law of the University of Zenica, Vol. 13, 2014., str. 8.-33.

24. Marongiu Buonaiuti, F., The EU Succession Regulation and third country courts, Journal of Private International Law, vol. 12, br. 3, 2016., str. 545.-565.

25. Weller, M., Mutual trust: in search of the future of European Union private international law, Journal of Private International Law, vol. 64, 2015., str. 82.-90.

26. Ugovor o funkcioniranju Europske unije (pročišćeni tekst), Službeni list C 326, 26. listopada 2012, str. 47.-390.

27. Uredba (EU) br. 650/2012 Europskog parlamenta i Vijeća od 4. srpnja 2012. o nadležnosti, mjerodavnom pravu, priznavanju i izvršavanju odluka i prihvaćanju i izvršavanju javnih isprava u nasljednim stvarima i o uspostavi Europske potvrde o nasljeđivanju, Službeni list EU L 201, 27. srpnja 2012., str. 107.-134.

28. Zakon o nasljeđivanju, Narodne novine, broj 48/2003, 163/2003, 35/2005, 127/2013, 33/2015. 
29. Zakon o zaštiti prirode, Narodne novine, broj 70/2005, 139/2008, 57/2011.

30. Zakon o zaštiti prirode, Narodne novine, broj 80/2013.

31. Zakon o provedbi Uredbe (EU) br. 650/2012 Europskog Parlamenta i Vijeća od 4. srpnja 2012. o nadležnosti, mjerodavnom pravu, priznavanju i izvršavanju odluka i prihvaćanju i izvršavanju javnih isprava u nasljednim stvarima i o uspostavi europske potvrde o nasljeđivanju, Narodne novine, broj 152/2014.

32. Turkish Act on Private International and Procedural Law (Act No. 5718), dostupno na: http://jafbase.fr/docAsie/Turquie/Private\%20international\%20law\%20Turkey.pdf, pristupljeno 10. svibnja 2018.

33. Succession and wills (Green Paper) $[\operatorname{COM}(2005) 65$ final - Not published in the Official Journal], dostupno na: http://eur-lex.europa.eu/legal-content/EN/TXT/ ?uri=LEGIS SUM: 116017, pristupljeno 21. svibnja 2018.

34. Case Mercredi C-497/10 PPU i case C. v. M. C-376/14 PPU.

35. Case Robert Swaddling v. Adjudication officer C-90/97, 25. veljače 1999.

36. Presuda Vrhovnog suda Republike Hrvatske Rev 3341/1993-2 od 23. lipnja 1994.

37. Presuda Ustavnog suda Republike Hrvatske U-IIIA/1335/2004 od 8. prosinca 2004. 


\section{DEVIATIONS FROM THE PRINCIPLE OF THE UNITY OF SUCCESSION IN THE EU REGULATION ON SUCCESSION}

\section{Summary}

Inheritance should be regulated by a predictable law that is closely connected to it. For the purpose of legal certainty and to avoid fragmentation of the succession, that law should regulate total inheritance, regardless of whether the property is situated in a Member State of the European Union or in a third state. EU Regulation on succession, in most cases, follows the principle of the unity of succession, however, it departs from it when a third country is involved in the inheritance proceeding. Thus, in cases related to third countries, the establishment of the correspondence between the jurisdiction and the applicable law has shown impossible, since the allocation of jurisdiction between the courts of the Member States in accordance with that Regulation does not take into account the possibility that in such cases the courts of third countries, with which inheritance has a significant link, have jurisdiction. In these cases, therefore, by division of jurisdiction on the courts of the Member State and the courts of third countries, it may come to fragmentation of succession, which entails the risk of parallel proceedings with possible different outcomes. The aim of the paper is to analyze in which cases the provisions of the Regulation result in fragmentation of succession and to suggest possible solutions. Finally, the proposed changes would enable the parties to agree that the courts of third countries of the chosen law have jurisdiction in settling the issue of inheritance, under the condition that these courts are then competent to decide on succession as a whole. In addition, the introduction of specific rules on the recognition and enforcement of decisions on succession issued by the courts of third countries in the Regulation would ensure greater uniformity in the treatment of these countries in relation to Member States and thus a greater degree of appreciation for a unified approach to succession.

Keywords: $\quad$ principle of unity of succession, EU Regulation on succession, jurisdiction, applicable law, third state.

This work is licensed under a Creative Commons

Attribution-NonCommercial 4.0 International License.

Katarina Knol Radoja, PhD, Assistant professor, Faculty of Law, University of Osijek, Stjepana Radića 13, 31000 Osijek, Republic of Croatia. Email address: kknol@pravos.hr. ORCID: https://orcid.org/0000-0003-0275-3076. 